\title{
A SURVEY OF WATER QUALITY MEASUREMENT SENSORS
}

\author{
Priyanka N. Bande ${ }^{1}$, S.J.Nandedkar ${ }^{2}$ \\ ${ }^{I}$ PG Student, Department of Electronics \& Tele-communication Engineering, Maharashtra Institute of Technology \\ Aurangabad, Maharashtra, India \\ ${ }^{2}$ Assistant Professor, Department of Electronics \& Tele-communication Engineering, Maharashtra Institute of \\ Technology Aurangabad, Maharashtra, India
}

\begin{abstract}
Water is an essential factor for sustaining life on earth andits adequate and safe supply must be accessible to all. As improved water quality is beneficial for health. Every possible effort should be made in that direction. Water quality depends on various physical and chemical standards such as color, turbidity, $p H$, temperature, DO (dissolved oxygen), conductivity and TDS (total dissolved solid).This paper presents a systematic survey of existing water quality measurement techniques which consist of traditional and modern approach of water quality analysis. It also includes a list of different water quality parameters and sensors used for quality analysis along with the standard quality range.
\end{abstract}

Keywords: Water Quality Analysis, Turbidity, pH, DO, TDS and Water Quality Sensors etc $* * *$

\section{INTRODUCTION}

Safe water is primary condition for health and also a basic human right but yet it is not accessible to all human kind. Due to which water related diseases increases day by day which causes 3.4 million deaths a year, mostly among children. Since there are many efforts made by government but still many people do not have access to improved water sources. In many developing countries contaminated water is being used for drinking without any proper former treatment. One of the reasons for this is unawareness in public and administration and the lack of water quality monitoring system which creates serious health issues. As water is the most important factor for all living organisms it is necessary to protect it and water quality analysis is first step taken in rational development and management of water resources [4].

Water quality is measure of suitability of water for particular use. It depends on various physical, chemical and biological parameters. Generally measured water quality parameters are temperature, turbidity, $\mathrm{pH}$, conductivity, dissolved oxygen (DO) and total dissolved solid (TDS).These parameters are measured routinely in order to maintain the good water quality.

\section{WATER QUALITY PARAMETERS}

Following are some of the important parameters which need to be measured for analyzing water quality:

\section{Temperature:}

Water temperature is one of the five important factors for water quality testing. It controls the rate of metabolic and reproductive activities and hence aquatic life cycle. If water temperature increases, decreases or fluctuate, these activities may speed up, slow down or stop. Thermoelectric power and heat resistance temperature sensor are most commonly used to detect water temperature. Water temperature is generally measured in Celsius $\left({ }^{\circ} \mathrm{C}\right)$.

\section{Turbidity:}

Turbidity is a measure of suspended particles present in water also called as cloudiness of water. It is mainly caused by suspended solids like soil particles and plankton (microscopic plants). These particles block the incident light and scatter or diffuse it. Therefore photoelectricity sensor is used to detect the turbidity of water. Turbidity sensor measures the turbidity level of water by measuring the amount of light scattered at 90 degree. Moderately low levels of turbidity indicate a healthy and safe water to drink while higher level of turbidity poses several problems. Higher turbidity of drinking water can provide food shelter to microbes and thus pathogens are more likely to present in such water. More turbid water can also raise the water temperature above normal as suspended particles in water absorb the heat from sunlight. Turbidity of water measured in unit called 'NTU' i.e. nephelometric turbidity unit. For water to be pure its turbidity should lie in range of 0 to 5 NTU.

\section{pH:}

$\mathrm{pH}$ is an important chemical factor of water. It is measure of acidity or basicity of a solution. It is based on concentration of $\mathrm{H}+$ or $\mathrm{OH}-$ ions present in water. $\mathrm{pH}$ scale is a logarithmic scale in which value changes in factor of 10 . The $\mathrm{pH}$ scale ranges from 0 to 14.If $\mathrm{pH}$ of a solution is less than 7 then the solution is acidic on the other hand ifpH value is greater than 7 then the solution is basic or alkaline and if $\mathrm{pH}$ of a solution is 7 then the solution is neutral. Normal water generally has $\mathrm{pH}$ value in between 6 to 9. The most common way of measuring $\mathrm{pH}$ of solution involves the use of $\mathrm{pH}$ sensitive glass electrode, a reference electrode and a $\mathrm{pH}$ meter which measures the difference in electrical potential between the $\mathrm{pH}$ electrode and the reference 
electrode and display the result converted into equivalent $\mathrm{pH}$ value.

\section{Conductivity:}

Conductivitydefines the ability of water to conduct electricity. This type of measurement accesses the concentration of ions in a solution.More the ions higher will be the conductivity. For water to be pure it's conductivity should be poor. Generally there are two types of conductivity sensors: two electrodes and multiple electrodes from which two electrodes sensor is commonly used. It is made by using two platinum plates deposited on two parallel glass or inner wall of glass tube. Conductivity of water measures in $\mu \mathrm{s} / \mathrm{cm}$ or $\mathrm{mA}$.

\section{Total dissolved solid (TDS):}

Total dissolved solids refer to the amount of minerals and salts present in the water. It combines the sum of all ion particles that are smaller than 2 microns. This includes all the disassociated electrolytes that increase the salinity concentration of water and other compounds such as dissolved organic matter. This term can be obtained by multiplying the conductivityterm by a factor usually taken as 0.67 . TDS of water is measured in unit $\mathrm{mg} / \mathrm{L}$. Freshwater can have maximum TDS as $2000 \mathrm{mg} / \mathrm{L}$.

TDS $=0.67 \times$ conductivity

\section{Dissolved oxygen (DO):}

It is amount of oxygen dissolved in water. DO measurement provide one of the best indicator for water ecosystem, as oxygen is essential for all forms of life. Oxygen enters water at water surface through direct exchange of with the atmosphere. The decrease in DO level indicates organic pollutant. DO levels vary in accordance with the weather and temperature. It is measured in unit $\mathrm{mg} / \mathrm{L}$. For safe water standard range of dissolved oxygen is $0-20 \mathrm{mg} / \mathrm{L}$.

\section{EXISTING TECHNIQUES}

There are different techniques available for water quality measurement which involves mainly two approaches traditional and modern.

\subsection{Traditional Approach}

Intraditional method, water parameters are detected by collecting samples manually and then send them to the wellequipped laboratories for further analysis where the testing equipments are stationary and samples are provided to the testing equipments. But this is a manual method with a tedious process and it has many disadvantages.

\section{Disadvantages:}

1) Require too much manpower and material resource.

2) Time consuming.

3) It has limitations of sample collecting.

4) Aging of experiment equipment.

5) Less reliable.

6) Lack of real time water quality information.

7) No on field monitoring.
8) It has relatively high costs (labor, operation and equipment).

\subsection{Modern Approach}

In order to overcome above mentioned disadvantages there is need to have autonomous, low cost, reliable and flexible water quality measurement system. Various advanced technologies for measuring water quality have been proposed in the recent years.

A sensor based wireless water quality monitoring system is proposed in which the data from monitoring nodes is send to the base station consisting of ARM controller and then sent to the remote monitoring station and then displayed on a server PC [4]. Now a days a wireless sensor network system is also becoming more popular which consist of high power Zigbee based technology together with the IEEE 802.15.4 compatible transceiver [5]. Most of the systems uses sensor circuitry for acquiring water quality parameters and send this data to the controller unit. The controller unit performs necessary actions and then delivers this data to the GSM module so that the data will be sent to the monitoring center in the form of SMS [1][4][6][9][10].

\subsubsection{Water Quality Sensors}

\section{Temperature Sensor}

LM 35

LM 35 is commonly used temperature sensor whose output voltage is linearly proportional to Celsius temperature. It is more accurate than thermistor. It does not require any external calibration or trimming to provide typical accuracies at room temperature over range $-55^{\circ} \mathrm{C}$ to $150^{\circ} \mathrm{C}$. It possesses low self-heating and does not cause more than $0.1^{\circ} \mathrm{C}$ temperature rise or fall. The output varies by $10 \mathrm{mV}$ with respect to every ${ }^{\circ} \mathrm{C}$ rise or fall in ambient temperature which means its scale factor is $0.01 \mathrm{~V} /{ }^{\circ} \mathrm{C}$ [8][10].

\section{DS18B20}

It is a digital temperature sensor, using single bus protocol. Operating temperature range is $-55^{\circ} \mathrm{C}$ to $+125^{\circ} \mathrm{C}$ and accuracy between $-10^{\circ} \mathrm{C} \sim 85^{\circ} \mathrm{C}$ is $\pm 0.5^{\circ}$ [1][7].

PT100

PT100 sensor is a temperature dependent component. Its resistance rises linearly with the temperature. Its operating temperature range is $-50^{\circ} \mathrm{C}$ to $+230^{\circ} \mathrm{C}$. It is low weight precise temperature measuring device with $\pm 0.5{ }^{\circ} \mathrm{C}$ accuracy. Its nominal resistance is $100 \Omega$ at $0^{\circ} \mathrm{C}$ and has no self-heating. It is available in 2 wire, 3 wire and 4 wire package [6].

\section{WQ 101}

WQ101 is a rugged reliable water temperature sensor that has two wire configurations for minimum current draw in which red wire is for supply and black is for output signal. Its operating temperature range is $-50^{\circ} \mathrm{C}$ to $+100^{\circ} \mathrm{C}$ with accuracy of $\pm 0.1^{\circ} \mathrm{C}$. It operates on 10 to $36 \mathrm{~V} \mathrm{DC}$ supply. It requires 5 seconds of warm up time. 
Table -1: Comparison of different temperature sensors

\begin{tabular}{|l|l|l|l|l|}
\hline $\begin{array}{l}\text { Sr. } \\
\text { No. }\end{array}$ & Name & $\begin{array}{l}\text { Operating } \\
\text { Range }\end{array}$ & Accu-racy & Applications \\
\hline 1 & LM 35 & -55 to $150^{\circ} \mathrm{C}$ & $\pm 0.5 @ 25^{\circ} \mathrm{C}$ & Soil \& water temperature measurement \\
\hline 2 & NTC Thermistor & -40 to $125^{\circ} \mathrm{C}$ & \pm 0.5 to $\pm 3 @ 50^{\circ} \mathrm{C}$ & $\begin{array}{l}\text { Temperature measurement sensing \& control in Industrial } \\
\text { and Consumer electronics }\end{array}$ \\
\hline 3 & DS18B20 & 55 to $125^{\circ} \mathrm{C}$ & $\pm 0.5^{\circ} \mathrm{C} @-10 \sim 85^{\circ} \mathrm{C}$ & $\begin{array}{l}\text { Temperature measurement which requires } 9 \text { to } 12 \text { bits of } \\
\text { resolution. }\end{array}$ \\
\hline 4 & RTD PT100 & -50 to $130^{\circ} \mathrm{C}$ & $\pm 0.5^{\circ} \mathrm{C}$ & $\begin{array}{l}\text { Temperature monitoring control \& switching in windings, } \\
\text { bearings, machines, motors, transformers \& many } \\
\text { industrial applications }\end{array}$ \\
\hline 5 & WQ101 & -50 to $100^{\circ} \mathrm{C}$ & $\pm 0.1^{\circ} \mathrm{C}$ & $\begin{array}{l}\text { Open water environmental monitoring applications such } \\
\text { as stream \& lake monitoring or aquaculture studies }\end{array}$ \\
\hline
\end{tabular}

\section{Turbidity Sensor}

Photoelectricity sensor

It works on phenomenon that, when light rays passed through waterthe amount of light scattered is equal to the turbidity of water. More the suspended particles more will be light scattered that means higher the turbidity of water. Photoelectricity sensor consists of LED at transmitter side and LDR at receiver side. When LED emits light the rays passes through water and scattered due to suspended particles present in water. LDR detect the scattered light rays and likewise measures the turbidity of water [6].

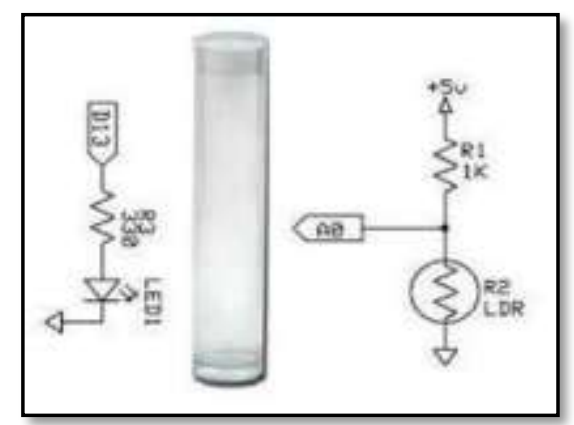

Fig -1: Turbidity sensor

\section{TSD 10}

This sensor also uses light to convey information about turbidity of water.As shown in Fig-2,it has two horns like structure having top to bottom mono material body with a black colored cap at the bottom. The thick alloyed contact legs provide means for various connectors to hold the sensor. TSD 10 turbidity sensor is shown below:

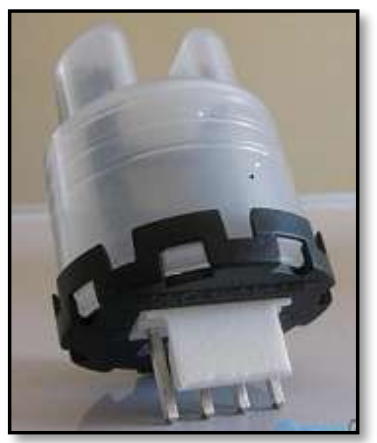

Fig -2: TSD 10 sensor
A white plastic slab protects the legs from damage and acts as fixture for good clamping. Outer part is covered with plastic so that it can survive high variations and mechanical abrasion. It works on $5 \mathrm{~V}$ DC supply and current up to $30 \mathrm{~mA}$. It operates on temperature ranging from $-10^{\circ} \mathrm{C}$ to $+90^{\circ} \mathrm{C}$

\section{TSW 10}

It is an optical sensor which is used as measuring product for turbid water density or an extraneous matter concentration using the refraction of wavelength between photo transistor and diode. By using an optical transistor and optical diode this sensor measures the amount of light coming from source of light to the light receiver in order to calculate water turbidity. It works on 5V DC supply and current max. Up to $30 \mathrm{~mA}$ over operating temperature range of $-30^{\circ} \mathrm{C}$ to $+80^{\circ} \mathrm{C}$. Internal structure of TSW 10 sensor is shown below:

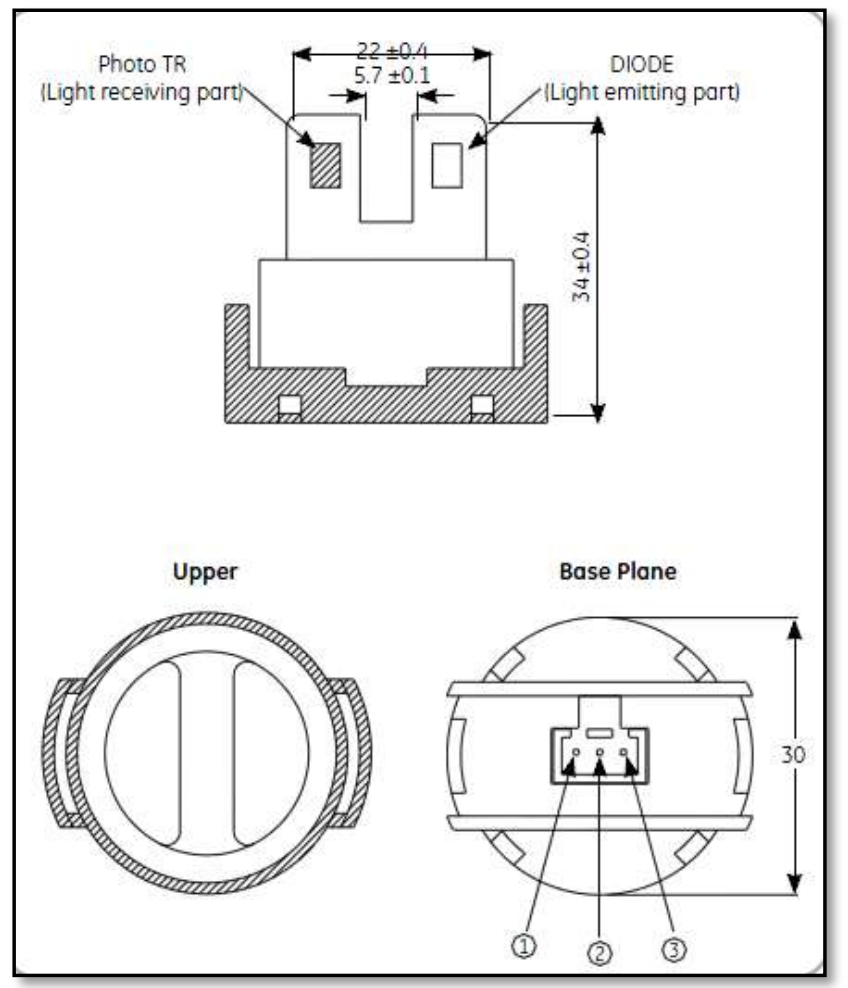

Fig -3: Internal structure of TSW 10 


\section{pH Sensor}

A $\mathrm{pH}$ glass probe is made up of special glass that can conduct electricity and allow only hydrogen ion. When glass probe touches the hydrogen ion the potential is produced. Likewise different $\mathrm{pH}$ in water generates corresponding potential [1]. It has $\mathrm{pH}$ value ranging from 0 to 14 . It operates on temperature range of 5 to $60^{\circ} \mathrm{C}$. The combined electrodes (glass and reference) are fitted with BNC type connector as in $\mathrm{pH}$ sensor module. Below the cap a hole is provided for filling the solution in internal reference electrode. It operates on 5V DC supply and current of 5 to $10 \mathrm{~mA}$. Its response time is $5 \mathrm{sec}$. and stability time is $60 \mathrm{sec}$. It has service life of 3 years and has analog voltage signal output.

\section{Conductivity Sensor}

Conductivity sensor circuit is same as that of photo resistor circuit. A voltage divider circuit consists of the conductivity sensor and a $10 \mathrm{k} \Omega$ resistor which is energized by setting high digital output. Some portion of $5 \mathrm{~V}$ dropped across sensor while remaining portion dropped across the $10 \mathrm{k} \Omega$ resistor. Conductivity sensor circuit is shown below:

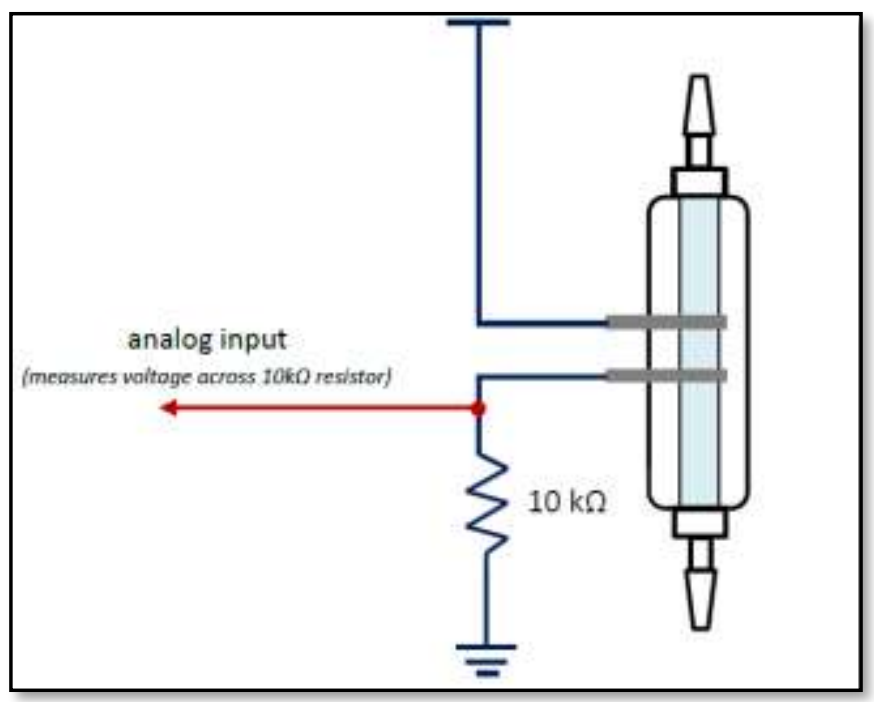

Fig -4: Conductivity sensor circuit

Voltage drop across $10 \mathrm{~K} \Omega$ resistor is measured by an analog input on ADC while voltage drop across conductivity sensor can be easily measured by making it the resistor closest to ground.

\section{DO Sensor}

\section{WQ 401}

It is a dissolved oxygen sensor which has three electrode structure and three wire configuration. If electrolyte deteriorates, the sensor can diagnose itself. Its temperature compensation can reach up to $25^{\circ} \mathrm{C}$ with output 4-20 mA. Its testing range is $0-8 \mathrm{ppm}$, accuracy is $\pm 0.5 \%$ of full scale, and operating temperature is $-40^{\circ} \mathrm{C}$ to $+55^{\circ} \mathrm{C}$. It is removable and easy to maintain [1].

\subsubsection{Water Quality Range}

Following table shows important water quality parameters as per IS 10500-2012 standards:
Table -1: Treated water standards

\begin{tabular}{|l|l|l|l|}
\hline $\begin{array}{l}\text { Sr. } \\
\text { no. }\end{array}$ & Parameter & Acceptable & $\begin{array}{l}\text { Cause of } \\
\text { rejection }\end{array}$ \\
\hline 1 & pH & 6.5 to 8.5 & $<6.5$ or $>9.2$ \\
\hline 2 & $\begin{array}{l}\text { Odour \& } \\
\text { Taste }\end{array}$ & Unobjectionable & Objectionable \\
\hline 3 & $\begin{array}{l}\text { Turbidity } \\
\text { (NTU) }\end{array}$ & 5 & 10 \\
\hline 4 & $\begin{array}{l}\text { Total } \\
\text { Dissolved } \\
\text { Solid (mg/lt) }\end{array}$ & 500 & 2000 \\
\hline 5 & $\begin{array}{l}\text { Conductivity } \\
(\mu \text { S/cm) }\end{array}$ & 500 & 600 \\
\hline 6 & $\begin{array}{l}\text { Total } \\
\text { Hardness } \\
(\text { mg/lt) }\end{array}$ & 300 & $<5$ \\
\hline 7 & $\begin{array}{l}\text { Dissolved } \\
\text { oxygen } \\
(\text { mg/lt) }\end{array}$ & 20 & 600 \\
\hline
\end{tabular}

\section{CONCLUSIONS}

Water quality measurement system measures the parameters of water like $\mathrm{pH}$, turbidity, temperature, conductivity, total dissolved solids and dissolved oxygen in order to detect the quality of water for deciding whether it is safe for drinking or not. From existing techniques available for quality measurement sensor based system is efficient, economical, convenient and fast than the traditional method. The sensor based system also has good flexibility as only by replacing sensors and small change in software programming this system can be used for measuring other water quality parameters as per their applications in industry or agriculture.

\section{REFERENCES}

[1]. Mo Deqing, Zhao Ying and Chen Shangsong, "Automatic Measurement and Reporting System of Water Quality Based on GSM", International Conference on Intelligent System Design and Engineering Application, 2012.

[2]. Theofanis P. Lambrou, Christos C. Anastasiou, Christos G. Panayiotou and Marios M. Polycarpou, "A Low Cost Sensor Network for Real Time Monitoring and Contamination Detection in Drinking Water Distribution Systems",IEEE Sensors Journal, Vol. 14,Issue 8,August 2014.

[3]. Theofanis P. Lambrou, Christos C. Anastasiou, Christos G. Panayiotou and Marios M. Polycarpou,"A Low Cost Sensor Network for Real Time Monitoring and Assessment of Potable Wtaer Quality at Consumer Sites",IEEE Sensors, October 2012.

[4]. Mithila Barabde,ShrutiDanve, "Real Time Water Quality Monitoring System",International Journal of Innovative Research in Computer and Communication Engineering,Vol. 3, Issue 6, June 2015.

[5]. ZulhaniRasin and Mohd Rizal Abdullah,"Water Quality Monitoring System Using Zigbee Based Wireless Network", International Journal of Engineering \& Technology, Vol.9, December 2009. 
[6]. Mr. Kiran Patil,Mr. SachinPatil, "Monitoring of Turbidity, $\mathrm{PH}$ and Temperature of Water Based on GSM",International Journal for Research in Emerging Science and Technology, Vol. 2, Issue 3, March 2015.

[7]. Vinay SwethiKorvi,Narendra Kumar, "Design and Implementation of Aqua Quality Monitoring System", International Journal of Research in Advent Technology, Vol. 1, Issue 5, December 2013.

[8]. T.Surya, M. Manoj Kumar, SD.Karmulla,CH. GopiNadh,P. Venkatesh and B.SitaMadhuri,"A Low Cost Sensor Network for Real Time Monitoring and Contamination Detection in Drinking Water Distribution Systems", Vol. 4,Issue 7,March 2015.

[9]. ThamaraiSelvi D.,Anitha S.R, "Potable Water Quality Monitoring and Automatic Billing System", International Journal of Advanced Research in Electrical,Electronics and Instrumentation Engineering,Vol. 4,Issue 4,April 2015.

[10].AkanshaPurohit and U.M.Gokhale, "Design and Implementation of Real Time Water Quality Measurement Using GSM", Vol. 2,Issue 1,January 2014. 